\title{
Medicinal Importance of Smilax ornata (Ushba) - A Unani Medicament
}

\section{Azma Waseem $^{1 *}$, Usama Akram² ${ }^{2}$ Waseem Ahmad ${ }^{3}$, Anwar Jamal ${ }^{1}$ and M Fazil $^{4}$}

${ }^{1}$ Research Officer (Unani), S-III, Hakim Ajmal Khan Institute for Literary and

Historical Research in Unani Medicine, Central Council For Research in Unani

Medicine, Ministry of AYUSH, Government of India

${ }^{2}$ Research Officer (Unani), Hakim Ajmal Khan Institute for Literary and

Historical Research in Unani Medicine, Central Council For Research in Unani

Medicine, Ministry of AYUSH, Government of India

${ }^{3}$ Technical Officer, Hakim Ajmal Khan Institute for Literary and Historical

Research in Unani Medicine, Central Council For Research in Unani Medicine,

Ministry of AYUSH, Government of India

${ }^{4}$ Research Officer (Unani), S-IV, Hakim Ajmal Khan Institute for Literary and

Historical Research in Unani Medicine, Central Council for Research in Unani

Medicine, Ministry of AYUSH, Govt of India, India

*Corresponding Author: Azma Waseem, Research Officer (Unani), S-III, Hakim

Ajmal Khan Institute for Literary and Historical Research in Unani Medicine, Central

Council For Research in Unani Medicine, Ministry of AYUSH, Government of India.
Received: September 30, 2021

Published: December 06, 2021

(C) All rights are reserved by Azma Waseem., et al.

\begin{abstract}
In the south Asia region, people show faith and mostly rely on the traditional system of medicines for the treatment of various ailments. The World Health organization (WHO) has also recognized the effectiveness and safety of the traditional system of medicine including Unani medicine. As we know that various plants also used in Unani medicine for medicinal purpose. Ushba (Smilax ornata) is a Unani drug that has been used singly or in combination for the treatment of various ailments like arthritis, ascites, fever, cough and many skin diseases like psoriasis, dermaphytosis, etc.. Phyto-chemical studies confirmed the presence of phytoconstituents like saponins, flavonoids, glycosides, carbohydrates, protein, starch and resins. Very less information is available about this plant drug. The aim and objective of this review is to provide the information on medicinal uses of Ushba maghribi (Smilax ornata) available in Unani system of medicine and recent advances through scientific studies conducted on the drug. It may help in development of a new drug for various ailments as most people of the world still rely on plant origin drugs for their primary healthcare.
\end{abstract}

Keywords: Ushba; Smilax ornata; Unani Drug; Research Studies

\section{Introduction}

Unani system of medicine is one of the ancient traditional systems of medicine. It is also a component of AYUSH that covers all traditional systems of medicine under one umbrella, practiced in subcontinent of India. As we know that plants have had historical significance in medicine since antiquity and utilized for the treatment purpose. Due to the abundance of plant, Plants origin drugs are readily accessible, affordable, and have safer sideeffects profile than synthetic drugs. It is estimated that two-thirds of the world's plant species have medicinal value. In Unani system of medicine plant origin drugs are mostly used for therapeutic purpose. The drug Ushba is a potent Unani drug botanically named as Smilax ornata [1] belongs to family Liliaceae [2]. It is also known as sarsaparilla in English [1,3]. There are several varieties of sarsaparilla, but the most common variety used for medicinal purpose is Smilax ornata formerly known as S. Regelii called Ushba or Ushba Maghribi [2,3]. Another drug with the name Ushba Hindi (Hemidesmus indicus) is also mentioned. Its leaves 
and stem resemble with the leaves of Jasmin plant [4,5]. Root of Hemidesmus indicus is black and known as Ziyan in Arabic [3,6]. It is also used for medicinal purpose and shows near about the same effects as Ushba Maghribi. The drug Smilax ornata (Ushba) is native of America ${ }^{1}$ and has been used there for medicinal purpose therefore known as Ushba Maghribi or Ushba Maghribiyya in Unani medicine [4]. Another name of Ushba is mentioned as Ushbat alNaar due to red coloured appearance of inner part of rhizome/root or excessive hiddat (heat producing effect) found in it $[4,7]$. It was also cultivated in Jamaica hence the prefix Jamaica is added with sarasaparilla and called as Jamaican sarsaparilla [2].

\section{Plant description}

It is a perennial climber with woody prickly stem, wrinkled and fibrous, found on loofy trees, springing from a stout, knotty rhizome. Stem is erect, and has very sharp thorns near abour $1 / 2$ inch long. Leaves are large, alternate stalks, almost evergreen and have prominent veins. Seven nerve midribs are strongly marked. Cortex is thick and brownish, with an orange red tint, and has slightly bitter and mucilaginous taste and tinges the saliva when chewed. Flowers are abundant, resemble with the flower of Indian jasmine, has greenish color and are very fragrant [4]. The root has no odour but has slightly bitter taste $[1,6,8]$. The bitter principle of root is used as flavoring agent. Root is whitish and reddish colored, about 3-4 inches long and fibrous [1]. They are shrunken and furrowed longitudinally and bear numerous root lets. Roots are tough and flexible and do not break easily. It is used as a beverage condiment for preparation of soft drinks and mostly used in combination with other aromatic plants. Branches and root of the plant is used for therapeutic purpose $[4,5]$. Best variety of Ushba is that which has moderate thickness and length, has reddish tint, exudes smoke/ dust when broken, and the inner part is whitish $[1,3,4]$. Shelf life of rhizome/root is about 20 years $[3,4]$.

\section{Part used (Musta 'mil Hissa)}

- $\quad \operatorname{Root}[1,2,7]$

- $\quad$ Root, branches and flowers [3,4]

- $\quad$ Root and branches [10].

Temperament (Mizaj) of the plant

- Hot and Dry [10]

- $\quad$ Hot $2^{0}$ last, Dry [3]

- $\quad$ Hot $3^{0}$ Dry $3^{0}[1,7]$ and fresh Ushba is Hot $2^{0}$ Dry $2^{0}[1]$.
Phytochemical constituents of Smilax ornata (Ushba):

The Smilax species have high concentration of phenolic compounds. Phytochemical constituents found in the rhizomes of Smilax ornata are alkaloids, flavanoid, glycoside, carbohydrate, protein, tannin, saponins, sarsaponin, parillin [9]. On hydrolysis yields dextrose, isomeric sarspogenin and smilogenin [9]. Other constituents in sarsaparilla include starch (50\%), resin, acetyl alcohol, volatile oil, shikimic acid, ferulic acid, sarsapic acid and fatty acids, kaempferol, and quercetin. Minerals reported in the genus include aluminum, chromium, iron, magnesium, selenium, calcium, zinc, and others $[9,11]$.

\section{Pharmacological action of Smilax ornata (Ushba)}

Following pharmacological actions of Ushba are mentioned in Unani Medicine [1,3-5,7,10].

It is anti-inflammatory (Muhaill-i Waram), alterative (Muaddil), liquefies viscous matter (Mulattif-i Mawad/Muraqqiq), blood purifier (Musaffi-i Khoon), diuretic (Mudir-i Bawl), diaphoretic (Mu'arriq), [3,4,7] purgative of morbid humour (Mushil-i Akhlat), liquefies semen (Muraqqiq-i Mani) and abortificient (Musqit-i Janeen) $[1,4]$. It is Muqawwi-i Kabid wa Meda (liver tonic and stomachic), acts as analgesic (Musakkin-i Alam) and included in various blood purifying formulations [3].

\section{Therapeutic indication of Smilax ornata (Ushba)}

It is useful for chronic skin diseases (Kohna Jildi Amraz), leprosy (Juzam), arthritis (Waja al-Mafasil) [9]. It is highly effective for the treatment of gout (Niqris) [1,3,10], and sciatica (Irq al-Nasa) $[4,7]$. It is beneficial for cold diseases of stomach, liver and brain [4], also useful in the treatment of kidney ailments and uterine diseases [1] ascites (Istisqa), renal and cystic pain (Waja al-Kuliyya wa Masana) [3]. Massage (Dalak) with its oil is beneficial for paralysis (Falij) [3,4] facial palsy (Laqwa) [1] pruritus (Kharish) [7,10], dryness of brain (Khushki-i Dimagh), cardiac asthma (Rabw), bronchial asthma (Zeeq-un Nafs), hemorrhoids (Bawaseer), mad dog bite (Gazeedgi-i Sag Deewana) and syphilis (Aatshak) [1,4]. It was used for the treatment of syphilis in Europe [12]. Sarsaparilla has been used for treating syphilis and other sexually transmitted diseases throughout the world and was documented as an adjuvant for leprosy treatment in 1959 [13]. It is suitable for the personnel having phlegmatic temperament (Balghami Mizaj) and effective in phlegmatic diseases (BalghamiAmraz) [3]. 
Dose (Miqdar)

- $\quad 4.5$ to $9 \mathrm{gm}[4]$

- 6-9 gm [10]

- $\quad$ Up to $9 \mathrm{gm}[1]$.

Toxicity and adverse effects (Muzir Asrat)

It causes combustion of blood (Ihtiraq-i Dam), increases heating effect of bile (Safra') [1], and not suitable to be used during acute fever, and other acute diseases like smallpox, chicken pox, etc. $[1,4]$. It is harmful for weak persons and personnel of hot and dry temperament. Though it is effective medicine for the melancholic diseases (Amraz-i Sawdavi) but its prolonged used increases heat and causes combustion (Ihtiraq) [3,10].

\section{Corrective (Musleh)}

- $\quad$ Cold distillate or extracts (Barid Araqiyat) and whey (Ma al-Jubn) [1,3]

- $\quad$ Almond oil (Roghan Badam) $[4,7,10]$.

Substitute:

- $\quad$ Smilax china (Chob chini) $[1,4,10]$

- $\quad$ Aged Smilax china (Chob chini kohna) [3].

Dosage forms

It is used in form of decoction (Matbookh): Oral administration of its decoction (Matbookh) is useful for paralysis (Falij), bronchial asthma (Zeeq al-Nafs) and chronic cough (Sual Muzmin) [4].

It is prepared as follows:

- $\quad$ Root (Bekh) and branches (shakh) of Smilax ornata (Ushba), each -16 gm are boiled with $420 \mathrm{ml}$ of water till half volume of water remains [3]. Another method of preparation of decoction is as follows [14].

- Ushba root- $2.25 \mathrm{gm}$ is cut into small pieces, ground and soaked in 8 cups of water overnight. In the morning, boiled till half volume of water remains, then filtered the water and drink as tea (Qahwa) daily for 4 days. The boiled drug remains is again soaked and boiled with 4 cups of water till half water remains. Repeat the process for 4 days. Drink the decoction sip by sip at night for 14 to 21 days. Decoction is beneficial for paralysis (Falij), chronic ascites (Istisqa Muzmin), bronchial asthma (Zeeq
al-Nafs) and chronic cough (Sual Muzmin) [3].

- Hakim Najmul Ghani has mentioned that a compound formulation (Majoon) prepared with Smilax ornata (Ushba) 85 gm, Casia senna (Sana) 36 gm, Foeniculum vulgare Mill. (Saunf) 12 gm, Pterocarpus santalinus Linn. (Sandal Surkh) 12 gm, Polypodium vulgare (Bisfayij) 12 gm, Ipomoea turpethum (Nasawt) $12 \mathrm{gm}$, Honey 18gm and sugar $18 \mathrm{gm}$, when used in a dose of $12 \mathrm{gm}$, is effective for syphilis (Aatshak). It removes the syphilitic matter, cleanses reproductive tract, useful for pruritus (Kharish), melasma (Kalaf), and joints pain (Waja al-Mafasil) also [1].

- There is found seven different formulations of Majoon Ushba in the book on Unani compound drugs 'Qarabadeen-i Azam', mainly prescribed as blood purifier (Musaffi-i Dam) and purgative (Mushil), that are useful for syphilis (Aatshak), arthritis (Waja al-Mafasil), pruritus (Kharish) and other skin problems (Jildi Amraz) [15].

- Nasal Drops (Saoot) prepared with Ushba root and Roghan Banafsha, is effective for migraine of cold type (Shaqeeqa Barid) $[3,4]$.

- Powder (Safuf): Oral administration of Powder (Safuf) of Ushba in a dose of 4.5 gm with sugar is beneficial for chronic arthritis (Waja al-Mafasil Muzmin) if taken for 7 days [3]. Ushba is included as an ingredient in a compound formulation 'Safuf chob chini' which is also useful for arthritis [15].

- $\quad$ Paste (Zimad) prepared with Ushba root and rose distillate (Arq Gulab) reliefs pain associated with arthritis and sciatica, reduces inflammation $[4,7]$ and also useful for paralysis [3].

- Vaginal Suppository (Humool): Ushba when used as vaginal suppository is abortifacient $[1,3,4]$.

- $\quad$ Liniment (Tila) or paste (zimad) prepared with Ushba is applied externally for the treatment of skin problems and malignant ulcers $[3,4]$.

- The compound known as Maa al-Usool (Roots Tonic) in Unani medicine is also prepared with Smilax ornata (Ushba) which is used for elimination of morbid matter in the treatment of arthritis. In Jamaica, root tonic prepared with Smilax ornata and other roots is consumed at home and sold locally as an energizer, aphrodisiac, for blood purification, and for the promotion and mainte- 
nance of good health [16].

- $\quad$ Oil (Roghan): Massage (Dalak) with its oil is effective in paralysis (Falij) [3].

Pharmacological studies on Smilax ornata (Ushba)

Antimicrobial activity

Antimicrobial activity of ushba against gram positive and gram negative bacteria, in alcoholic and aqueous extract of Ushba has been reported by Ahmad and Khan. The highest antimicrobial activity of Ushba was observed in alcoholic extract. Alcoholic extract showed effective antibacterial activity against the Streptococcus pyogens whereas aqueous extract showed moderate antibacterial activity against gram positive bacteria and is found more effective for Staphylococcus aureus. In Gram negative bacteria strains, both extracts showed moderate results against Klebsiella pneumonia and Pseudomonas aerugenosa. Aqueous extract also showed mild activity against E. coli [17].

Anti-inflammatory and analgesic activity

Khan., et al. reported that methanol and ethyl acetate extracts of Smilax ornata (Ushba) exhibits anti-inflammatory and analgesic activity in arthritis and rheumatic pain using carrageenan induced paw edema and tail flick model in Sprague Dawley rats. The methanol extracts (200 and $400 \mathrm{mg} / \mathrm{kg}$ ) and the ethyl acetate extract $(400 \mathrm{mg} / \mathrm{kg})$ exhibited significant $(\mathrm{P}<0.05)$ anti-inflammatory activity when compared with that of their control groups (saline and vegetable oil respectively), with an onset of $150 \mathrm{~min}$ and a duration of $2.5 \mathrm{~h}$. The methanol extract $(200 \mathrm{mg} / \mathrm{kg})$ exhibited significant $(\mathrm{P}<0.05)$ analgesic activity, with an onset of $60 \mathrm{~min}$ and a duration of $2 \mathrm{~h}$. Also, the methanol and the ethyl acetate extracts $(400 \mathrm{mg} /$ $\mathrm{kg})$ exhibited significant $(\mathrm{P}<0.05)$ analgesic activity when compared with that of their control groups (saline and vegetable oil respectively), with an onset of $30 \mathrm{~min}$ and a duration of $2.5 \mathrm{~h}$ [18].

\section{Anti-arthritic effect of Majoon Ushba}

In a clinical study efficacy of Majoon Ushba was investigated and its underlying mechanism in adjuvant induced arthritis (AIA) in right hind paw of Wistar albino rats. Majoon Ushba $(100 \mathrm{mg} / \mathrm{kg} / \mathrm{b}$. wt) was given for 8 days after induction of arthritis. The result showed that it increased the level of anti-inflammatory cytokines (IL-10), inhibited the production of pro-inflammatory cytokines, suppressed the NF-kB, AP-1 and cytokines mRNA expression, suppresses the IL-17 and COX-2 protein expression and regulates RANKL and OPG protein expression. Study confirmed Majoon Ushba as an anti-arthritic drug [19].

\section{Effect of majoon ushba in Da-us- Sadaf (Psoriasis)}

A randomized single-blind placebo controlled study was conducted to assess the safety and efficacy of two pharmacopeial Unani formulations - Majoon Ushba and Roghane Hindi, in the management of psoriasis on scientific parameters. The experimental group comprised 20 patients to whom Majoon Ushba 5 gm was administered orally twice daily, and Roghane Hindi was applied locally twice daily. The control group comprised 10 patients were given placebo drugs orally and topically. The duration of the trial was 8 weeks and follow-up was done fortnightly. The severity of psoriasis and efficacy of the drug was assessed by the Psoriasis Area and Severity Index (PASI) Scale. The study confirmed the safety and efficacy of both the drugs in psoriasis [20]. Ahmad., et al. has also reported the efficacy and safety of Majoon Ushba (containing ushba as ingredient) and Marham Safeda in the management of psoriasis in a clinical trial [21].

Effect of majoon ushba in Qooba (dermaphytosis)

Tariq., et al. reported efficacy of Majoon Ushba and Marham Gulabi in dermaphytosis (Qooba). Clinical study was conducted on 30 patients suffering from dermaphytosis to evaluate the efficacy of Majoon Ushba and Marham Gulabi. Study was carried out for 45 days. The efficacy was evaluated on the basis of improvement in the clinical subjective parameters such as itching, scaling, oozing erythema, papules, fissures, partially alopecia, broken stumps of hair, kerion formation and ring formation with central clearing. Both drugs found effective for Qooba (dermaphytosis) [22].

\section{Adulterants}

Smilax ornata (Ushba) is commonly adulterated throughout its history of use. The most common adulterant and still used, is Hemidesmus indicus (Ushba Hindi), the Indian sarsaparilla which has near about same pharmacological activities. The two drugs can be distinguished if examined. Ushba Hindi has more dark brown color, slight bitter and strong smell of vanilla whereas, smilax ornata (ushba) has light color and bland taste. Other adulterants are Carex arenaria (German sarsaparila), and other species of Smilax [3]. Determining the presence of sarsaponin, through Thin-layer chromatography (TLC) might help to rule out adulterants [23].

\section{Conclusion}

It can be concluded from the above review that ushba is a traditionally and clinically proven plant for both its efficacy and application. It is considered to be safe herbal drug as confirmed by 
scientific studies. Smilax ornata (Ushba) is a potent plant drug having wide range of medicinal activities like, analgesic, anti-inflammatory, anti- syphilitic, blood purifier, anti artharlgic activity etc., and is beneficial for various ailments. Some of pharmacological activities are scientifically proven as well. Though it has a various medicinal properties but very less is known about the morphology of the plant and still very few studies have conducted on its medicinal activities. More designed studies are needed to comprehend the multi-target pharmacology and to ascertain the doses of Smilax ornata. There is an immense necessity to evident and explore it medicinal values at molecular levels, using biotechnological tools.

\section{Bibliography}

1. Ghani MN. Khazain al-Advia, Central Council for Research in Unani Medicine. New Delhi (2010): 121-123.

2. Nadkarni KM. Indian Materia Medica. Bombay Popular Prakashan Bombay 1 (1995): 1144-1145.

3. Khan MA. Muheet-i Azam (Urdu translation), Central Council for Research in Unani Medicine, New Delhi. 3 (2014): 574-575.

4. Shirazi MMH. Makhzan al-Advia, (Persian), Matba Ahmadi, Shahdara, Delhi 1378 AH: 421-422.

5. Safiuddin HS. Unani Advia Mufradah, Qaumi Urdu Council Barae Farokh Urdu Zaban, New Delhi. (2010): 202-203.

6. Usman MI. Tanqeeh al-Mufradat, Ibn Sina Tibbiya College, Azamgarh (2008): 172.

7. Kabiruddin M. Makhzan al-Mufradat, Showkat Book depot Gujarat. (YNM) 409-410.

8. Wallis TE. Textbook of Pharmacognosy), CBS Publishers and distributer, Shahdara, Delhi (1985): 612-613.

9. Ahmad R and Khan NA. "Physico-chemical and Phyto-chemical study of Unani drug Ushba (Smilax ornata". Indian Journal of Unani Medicine 11.1 (2018): 32-37.

10. Nabi G., Mufradat wa Murakkabat. Central council for Research in Unani medicine, New Delhi (2007): 169.

11. Newall C., et al. Herbal Medicines: A Guide for Healthcare Professionals. London, England: Pharmaceutical Press (1996): 233-234.

12. Wilson H. "Sarsaparilla in syphilis". Provincial Medical Journal and Retrospect of the Medical Sciences 6.134 (1843): 71.

13. Rollier R. "Treatment of lepromatous leprosy by a combination of DDS and sarsaparilla (Smilax ornata)". The International Journal of Leprosy 27 (1959): 328-340.
14. Jalaluddun Amrohavi Qarabadeen Jalali. Central council for Research in Unani Medicine. New Delhi (2019): 89-92.

15. Khan MA, Qarabadeen-i Azam. "Central Council for Research in Unani Medicine”. New Delhi (2009): 486-488.

16. Ina Vandebroek., et al. "Root Tonics and reliance: Building Strength, health, and heritage in Jamaica". Frontiers in Sustainable Food Systems (2021). https://www.frontiersin.org/articles/10.3389/fsufs.2021.640171/full accessed on 24.09.2021

17. Ahmad R and Khan N. "A short review and study on antimicrobial activity of Unani drug-Ushba (smilax ornata)". Journal of Drug Delivery and Therapeutics 9:1-s (2019): 347-350.

18. Khan Ak., et al. "Investigation of the anti-inflammatory and analgesic effect of the extracts of Smilax ornata (Jamaican sarsaparilla)". Journal of Ethnopharmacology 240 (2019): 11830.

19. Ganeshan R., et al. "Majoon ushba, A poly herbal compound ameliorates rheumatoid arthritis via regulating inflammatory and bone remodeling markers in rats". Cytokines 77 (2016): 115-126.

20. Lone AH., et al. "Clinical evaluation of efficacy of Majoon Ushba and Roghane Hindi in the management of psoriasis: A randomized single-blind, placebo-controlled study". Journal of Ayurveda and Integrative Medicine 2.1 (2011): 26-31.

21. Ahmad A., et al. "Clinical evaluation of efficacy of Majoon Ushba and Roghane Hindi in the management of Da us-Sadaf (psoriasis)". International Journal of Pharmaceutics 11.4 (2021): $1-6$.

22. Tariq Hasan SS., et al. "Clinical evaluation of efficacy of Majoon Ushba and Marham Gulabi in Qooba (dermaphytosis)". Indian Journal of Traditional Knowledge 10.4 (2011): 702-705.

23. Christropher H. "Sarsaparilla A literature review". HerbalGram Published by the Herb Research Foundation and the American Herbal Products Association 17 (1988): 10-14.

\section{Assets from publication with us}

- Prompt Acknowledgement after receiving the article

- Thorough Double blinded peer review

- Rapid Publication

- Issue of Publication Certificate

- High visibility of your Published work

Website: www.actascientific.com/

Submit Article: www.actascientific.com/submission.php

Email us: editor@actascientific.com

Contact us: +919182824667 